\title{
UTRATA DOMEN PRZEZ JEZYK DUŃSKI - CZY JĘZYK DUŃSKI JEST ZAGROŻONY?
}

\author{
ANDRZEJ SZUBERT
}

Można sobie zadać pytanie, jaka będzie przyszłość porozumiewania się w XXI wieku? Globalny rozwój oznacza, że ludzie mają potrzebę komunikowania się ponad granicami krajów i w praktyce język angielski stał się światowym lingua franca. W Skandynawii nie jest niczym nowym, że języki inne niż własne języki narodowe w różnych okresach używane były w wielu sferach społecznych. Przed 500 laty językiem nauki była łacina i było tak do XIX wieku. W handlu i rzemiośle przez wiele lat dominował język niemiecki. Bardzo wysoki prestiż miał język francuski. Dzisiaj wszystkie te funkcje przejmuje język angielski.

Do X-XI wieku mieszkańcy Północy mówili najprawdopodobniej wzajemnie zrozumiałymi wariantami języka duńskiego - „den danske tunge” - jak traktowano języki nordyckie pod jedną nazwą. Dopiero po tym okresie można mówić o wyodrębnieniu się języka duńskiego i innych nordyckich. Jednak język duński potrzebował czasu, aby przebić się w wielu sferach życia, bo jako język nabożeństw stało się to w pełni dopiero w XVI wieku, w nauce łacina ustępuje mu pola dopiero w XVII wieku, a w teatrze dzięki komediom Ludviga Holberga w XVIII wieku. Ostatnie bastiony łaciny i języka niemieckiego legły dopiero w XIX wieku, kiedy to język duński zaczął obowiązywać w szkolnictwie, nauce, wojsku i wielu innych dziedzinach. Dzisiaj to język angielski dominuje w wielu sferach życia, m.in. w nauce, handlu międzynarodowym, reklamie, jest praktycznym językiem roboczym i pomocniczym w wielu firmach i międzynarodowych mediach. M. Herslund (1999: 22) zauważa, że językiem reklamy w Danii jest język angielski.

W świecie informatyki czy Internetu język angielski stał się językiem światowym i wielu twierdzi, że globalna przyszłość będzie wyrażana po angielsku. 
Jak jednak twierdzi duński językoznawca Jørn Lund ${ }^{1}$, przytaczając w Politiken (11.11.2000) pewną anegdotę dla wyjaśnienia, jaki wpływ wydarzenia historyczne mogą mieć na rozwój języka. Otóż pewien norweski profesor, będący gorącym zwolennikiem języka nynorsk, uważał niedawno, że bitwa pod Stamford Bridge na wschód od Yorku w Anglii (1066) miała dramatyczne następstwa dla rozwoju języka na świecie. Angielski król Harald Godwinson zwyciężył norweskiego Haralda Hårderåde (Srogi) i zatrzymał tym samym norweską ekspansję w Anglii. W przeciwnym razie mówiono by po norwesku w USA. Nie mówilibyśmy na całym świecie OKAY, lecz GREITT. Amerykański jest przecież językiem emigrantów. Stało się jednak inaczej i należałoby zadać pytanie, czy obawy o to, że język angielski wyprze język duński z wielu sfer życia, bądź wręcz doprowadzi do jego wymarcia, są słuszne?

- Ponad 1.400.000.000 osób żyje w krajach, gdzie język angielski jest językiem oficjalnym.

- Ok. 1/4 ludności świata mówi co najmniej dobrze po angielsku.

- Ok. 1 mld ludzi właśnie się go uczy. ${ }^{2}$

Dansk Sprognaevn (samodzielna instytucja naukowo-badawcza, zajmująca się monitorowaniem i normowaniem języka duńskiego, podległa bezpośrednio Ministrowi Kultury), Minister Kultury i wiele partii politycznych zgadzają się co do tego, że należy ustalić duńską politykę językową, która ma zapewnić, że język duński pozostanie językiem kompletnym, przy pomocy którego można wszystko wyrazić (zob. Politiken 19.3.2002 za http://eplads.norden.org/nordens sprak/kap6/6c.asp). Angielski/amerykański język i kultura rozszerzyła się w ostatnich 50 latach do tego stopnia, że wiele krajów europejskich próbuje powstrzymać te wpływy z obawy o to, że ich języki narodowe i kultury upadną. W 1969 P. Lindegaard Hjort pisał w Dagbladet Aktuelt, że przez cały XX wiek jesteśmy narażeni na kolosalne wpływy języka angielskiego. Nie jest zatem niczym nierealnym, że cała administracja, nauczanie i biznes będą się odbywały w języku angielskim za 20-30 lat. Tak źle się jednak nie stało, choć językoznawcy ostrzegają przed utratą domen ${ }^{3}$. I.L. Pedersen (2000: 34) pisze około 30 lat później, że wszystkie żywe języki, zmieniają się, albo raczej, że to my jako użytkownicy je zmieniamy. W obu przypadkach traktowane jest to jako coś negatywnego. Zmiany językowe powodują zmartwienie i stąd część polityki językowej poświęcana jest ich przeciwdziałaniu.

Zdaniem Jarvad (1999b: 114) język angielski ma wysoki prestiż w pewnych środowiskach. Używa się tam całych zdań w języku angielskim pokazując, że to właśnie ten język jest właściwy, kiedy mowa jest o jakości i stylu życia.

\footnotetext{
${ }^{1}$ http://eplads.norden.org/nordenssprak/kap6/6b.asp?lang=da (31-03-2014)

${ }^{2} \mathrm{http}$ ://eplads.norden.org/nordenssprak/kap7/7d.asp

${ }^{3} \mathrm{http} / / /$ eplads.norden.org/nordenssprak/kap7/7e.asp
} 
Jak zaznaczają Davidsen-Nielsen i Herslund (1999: 17) wpływ języka angielskiego na inne języki, w tym duński, odzwierciedla dominację kulturową krajów angielskojęzycznych, a szczególnie Stanów Zjednoczonych. Wpływ ten może być wzbogaceniem, a jeśli miałby on mieć negatywny wpływ na język duński, to nie powinien móc się rozwijać w sposób swobodny i niepohamowany.

Jarvad (2001: 147) sądzi, że język angielski jest bardzo zauważalny w komunikacji wewnętrznej wielu przedsiębiorstw i że stał się w nich językiem roboczym, a w szczególności w tych dużych.

Również Herslund (1999: 22-23) jest podobnego zdania i według niego coraz więcej firm w Danii przybiera angielskie nazwy, a komunikacja w przedsiębiorstwach odbywa się w języku angielskim. Uważa on, że jest to niepokojące zjawisko oraz że język duński traci swój status.

Wypowiada się w tej kwestii również F. Larsen (1999: 28), który pisze, że żyjemy w czasach, w których dominującym językiem obecnym jest język angielski. Dodaje on jednak, że obecność języka angielskiego w języku duńskim istnieje od dawna i obejmuje od zasymilowanych zapożyczeń znajdujących się w słownikach, poprzez nowe i znane, choć nieakceptowane, po takie, których nie można uznać za przejęte i które zapewne nie przetrwają w języku.

Kraje nordyckie stworzyły w kwestii wpływów języka angielskiego bardzo różne strategie, jeśli chodzi o import wyrazów obcych - od protekcjonistycznych do bardzo liberalnych. Lecz nawet w Danii, gdzie jest tradycja pozwalająca językowi na swobodny rozwój, Ministerstwo Kultury rozesłało w 2003 roku raport, który umieszczono na stronie ministerstwa (www.kum.dk.), dotyczący polityki językowej (Sprog på spil) z zaleceniami mającymi na celu wzmacnianie języka duńskiego. W Szwecji podobna sprawa odnośnie tejże polityki pojawiła się w Mål i mun ${ }^{4}$.

\section{Czym jest utrata domen?}

Obawy, że język duński traci zasięg użycia, dotyczy dziedzin, w których język angielski jest ,jednowładcą”, i dlatego w tych dziedzinach język duński się nie rozwija. Nazywamy to utratą domen, czyli jest to przejęcie zakresu słownictwa jednego języka w jakiejś dziedzinie przez słownictwo innego języka. Zapożyczanie dotyczy szczególnie takich dziedzin życia, jak media, handel i technologie. Pojawiają się nowe pojęcia, przedmioty i trzeba je nazwać. Można je oczywiście tłumaczyć na język duński i tak np. ang. edit bez problemu może stać się duń redigér, ale już drag and drop nie bardzo można przetłumaczyć bezpośrednio na trak og slip, ponieważ tego zwrotu używa się na spłuczkach w toaletach. Czasami proponuje się jakiś nowy duński termin, np. fastpladelager zamiast

\footnotetext{
${ }^{4}$ http://regeringen.se/sb/d/108/a/1443
} 
harddisk, ale się nie przyjął. Jednak user interface stało się brugergranseflade. Formy luftpude, luftpose czy sikkerhedspude (w analogii do sikkehedssale) przegrały z kretesem z airbag, który się w pełni zasymilował z duńskim systemem odmiany (por. -gen, -s, -gene/-sene).

Problemem wpływów angielskich w języku duńskim zainteresowano się szerzej już w latach 80. XX wieku. Nie sposób omówić wszystkie dziedziny, w których mamy do czynienia $\mathrm{z}$ utratą domen, natomiast jest to bardzo reprezentatywne na przykładzie nauki.

Paradoksalnie równolegle do działań zmierzających do ochrony języka duńskiego Kolegium Rektorów i Ministerstwo Nauki utworzyło grupę roboczą, która stwierdziła, że należałoby zaoferować więcej możliwości kształcenia w języku angielskim, mówiąc:

„Udgangspunktet for gruppens overvejelser har været, at skal danske uddannelsesinstitutioner gøre sig gældende på et internationalt uddannelsesmarked og tiltrække såvel udenlandske studerende som udenlandske lærere, er det nødvendigt, at der udbydes undervisning både $\mathrm{i}$ form af enkeltkurser og hele uddannelser på fremmedsprog, primært engelsk."

„Punktem wyjścia do rozważań grupy było to, że jeśli duńskie instytucje kształcące mają zaistnieć na międzynarodowym rynku kształcenia i przyciągać zarówno zagranicznych studentów jak i nauczycieli, konieczne jest zaoferowanie nauki zarówno w formie pojedynczych kursów oraz całych cykli kształcenia w językach obcych, głównie w języku angielskim." (tłum. autora)

Dalej w tym tekście czytamy:

„Udbuddet af fremmede undervisningstilbud bør være af international standard både fagligt og sprogligt.” (ibid.)

„Wachlarz ofert nauczania w językach obcych winien spełniać międzynarodowe standardy zarówno pod względem merytorycznym jak i językowym.” (tłum. autora)

Na duńskich uczelniach naucza się coraz więcej w języku angielskim, ale czy spełnia to oczekiwania im postawione?

\section{English}

Większość nauczycieli, którzy próbowali uczyć w języku angielskim, zna to ograniczenie, mogąc powiedzieć tylko to, co potrafi, zamiast tego, co się chce powiedzieć - stwierdził Davidsen-Nielsen w Politiken ${ }^{6}$ (18.01.2010). Ostrzega

${ }^{5}$ www.rks.dk, 20.03.2001, za P. Jarvad 2001: 93-94).

${ }^{6} \mathrm{http} / / /$ eplads.norden.org/nordenssprak/kap6/6b.asp?lang=da (31-03-2014). 
on przed wyparciem języka duńskiego z duńskich uczelni przez język angielski, argumentując to tym, że:

- spada poziom fachowości (ani studenci, ani prowadzący zajęcia nie są w stanie wyrażać się wystarczająco precyzyjnie w języku angielskim),

- jeśli dany badacz jest tylko w stanie przekazywać swoją wiedzę w języku angielskim, to wiedza ta nie dotrze do zwykłego Duńczyka,

- mitem jest, że każdy w Danii mówi po angielsku.

Duńczycy porozumiewają się $\mathrm{w}$ języku angielskim, ale jest to „lufthavnsengelsk" - ,angielski lotniskowy”. Zastanawia się on również, czy warto wykorzystywać czas i zasoby w celu podnoszenia kwalifikacji językowych nauczycieli i studentów. Wielu Duńczykom wydaje się, że znają język angielski, ale mimo wszystko nigdy nie będzie on na takim samym poziomie jak język ojczysty. Davidsen-Nielsen nie ma natomiast obaw o zapożyczenia z języka angielskiego w języku codziennym.

Można tu zadać pytanie, czy studiowanie jakiegoś kierunku w języku obcym ma tylko zalety.

Utratę domen przedstawić można chyba najbardziej reprezentatywnie na podstawie publikacji naukowych z różnych dziedzin nauki. Jarvad opublikowała wyniki badań przeprowadzonych w latach 90-tych XX wieku obrazujących publikacje z różnych dziedzin nauki. Tabele poniżej przedstawiają sytuację.

Wydziały teologiczne, humanistyczne i nauk społecznych w roku 1990: (P. Jarvad 2001: 106),

\begin{tabular}{|c|c|c|c|c|c|}
\hline \multicolumn{3}{|c|}{ Artykuły } & \multicolumn{3}{c|}{ Książki } \\
\hline Język duński & Język angielski & Inne & Język duński & Język angielski & Inne \\
\hline $59 \%$ & $31 \%$ & $10 \%$ & $73 \%$ & $17 \%$ & $10 \%$ \\
\hline
\end{tabular}

Jeśli natomiast chodzi o nauki medyczne i przyrodnicze razem wzięte, to artykułów w języku angielskim jest $82 \%$, a książek $84 \%$.

Centrum Badawcze Ris $\varnothing$ (Forskningscenter Ris $\varnothing$ ) (por. Jarvad 2001: 112) przeprowadziło z kolei badanie obrazujące zmiany w zakresie publikacji w ciągu 10 lat i jeśli porównać statystyki w naukach przyrodniczych, to wygląda to następująco:

Fizyka i chemia materiałowa

\begin{tabular}{|c|c|c|c|c|}
\hline \multicolumn{3}{|c|}{ Artykuły } & \multicolumn{2}{c|}{ Książki } \\
\hline Rok & Język duński & Język angielski & Język duński & Język angielski \\
\hline 1990 & $0 \%$ & $100 \%$ & $13,5 \%$ & $86,5 \%$ \\
\hline 2000 & $2 \%$ & $98 \%$ & $0 \%$ & $100 \%$ \\
\hline
\end{tabular}




\section{Medycyna}

\begin{tabular}{|c|c|c|c|c|c|c|}
\hline \multicolumn{4}{|c|}{ Artkuły } & \multicolumn{3}{c|}{ Książki } \\
\hline Rok & Język duński & Język angielski & Inne & Język duński & Język angielski & Inne \\
\hline 1990 & $8 \%$ & $91 \%$ & $1 \%$ & $30 \%$ & $68 \%$ & $2 \%$ \\
\hline 1999 & $16 \%$ & $83 \%$ & $1 \%$ & $44 \%$ & $52 \%$ & $4 \%$ \\
\hline
\end{tabular}

Wielu badaczy duńskich mimo różnych sygnałów obaw nie widzi niebezpieczeństwa, jeśli chodzi o język duński i jego dalszą obecność na mapie języków świata. Twierdzą oni, że językowi angielskiemu daleko jeszcze do wpływów na języki nordyckie, jakie miał w XV wieku język dolnoniemiecki czy w XVIII wieku francuski. Zapożyczane są nowe wyrazy, żeby móc mówić o pojawiających się nowych zjawiskach, jak np. Internet, jednak język to przyjmie, a liczby nie są jednak drastyczne.

\section{Statystyka}

W Danii przeprowadzono wiele badań statystycznych dotyczących wpływów języka angielskiego oraz liczby zapożyczonych leksemów i tak Brink (1988: 4) twierdzi na podstawie badania opartego na krótszych tekstach (po ok. 200 słów), że tylko 1-2\% wyrazów jest pochodzenia angielskiego. W języku mówionym nie jest ich więcej niż 0,5\%. Wśród 1000 najczęściej używanych wyrazów w języku duńskim, które stanowią $75 \%$ wszystkich duńskich tekstów, jest ok. 10 pochodzących z języka angielskiego, takich jak: weekend, radio, cykel, job, okay itp. Inne badanie przeprowadziła Jarvad (1995: 109), analizując różne teksty. Oparła je na korpusie ok. 100.000 wyrazów i średnia wyniosła $0,2 \%$ wyrazów pochodzenia angielskiego. W publikacji literaturoznawczej było tylko $0,01 \%$, a największą wartość, tj. $1,1 \%$, osiągnięto w publikacji książkowej o marketingu.

Są jednak dziedziny, w których udział słownictwa angielskiego jest wyższy i tak np. w reklamie, ekonomii, naukach przyrodniczych, kulturze (pop) i in. może dojść do 25\% wyrazów pochodzenia angielskiego. Sørensen (1995: 57) badał z kolei różne części mowy, bazując na korpusie 5.516 wyrazów. Z badania wynika, że rzeczowniki pochodzenia angielskiego stanowiły $81 \%$, czasowniki 9\%, przymiotniki $8 \%$, a pozostałe $0,88 \%$. Hansen (1985: 69) zbadał natomiast słownictwo pod względem złożoności struktury. Z 315 angielskich wyrazów prostych $18 \%$ zostało przetłumaczonych na język duński, np. afskrcekkelsesvåben (detterent), langtidsleje (lease), a z ok. 390 wyrazów złożonych przetłumaczonych zostało już 72\% nedtcelling (count down), tebrev (tea bag), ikkevoldelig (non-violent), frysetørre (freeze dry). Wyrazy proste są trudniejsze 
do przetłumaczenia i dlatego często pozostają w formie oryginalnej, np.: camp, lobby, rock, squash itp.

W Norwegii i Szwecji debata na temat języka ojczystego jest dużo bardziej widoczna niż w Danii. Szczególnie w Norwegii jest ona bardzo świadoma. Duńczycy mają zdaje się bardziej takie nastawienie, że ,język żyje swoim życiem, w które nie należy ingerować".

Chcąc sprawdzić, jakie jest faktyczne zagrożenie dla języka duńskiego, można spojrzeć na szwedzkie badanie pokazujące rozłożenie obcego słownictwa w słownictwie szwedzkim, co ilustruje poniższy wykres. I tak w pionie widać odsetek słownictwa pochodzącego z danego języka (w kolejności od dołu: wyrazy rodzime, język niemiecki, łacina i greka, francuski, angielski, inne języki, niż podano wcześniej, wyrazy niewiadomego pochodzenia, zanik (cyfry, zaimki itp.), a w poziomie podano pierwszych 6.000 wyrazów wg frekwencyjności użycia, podzielonych na poszczególne tysiące.

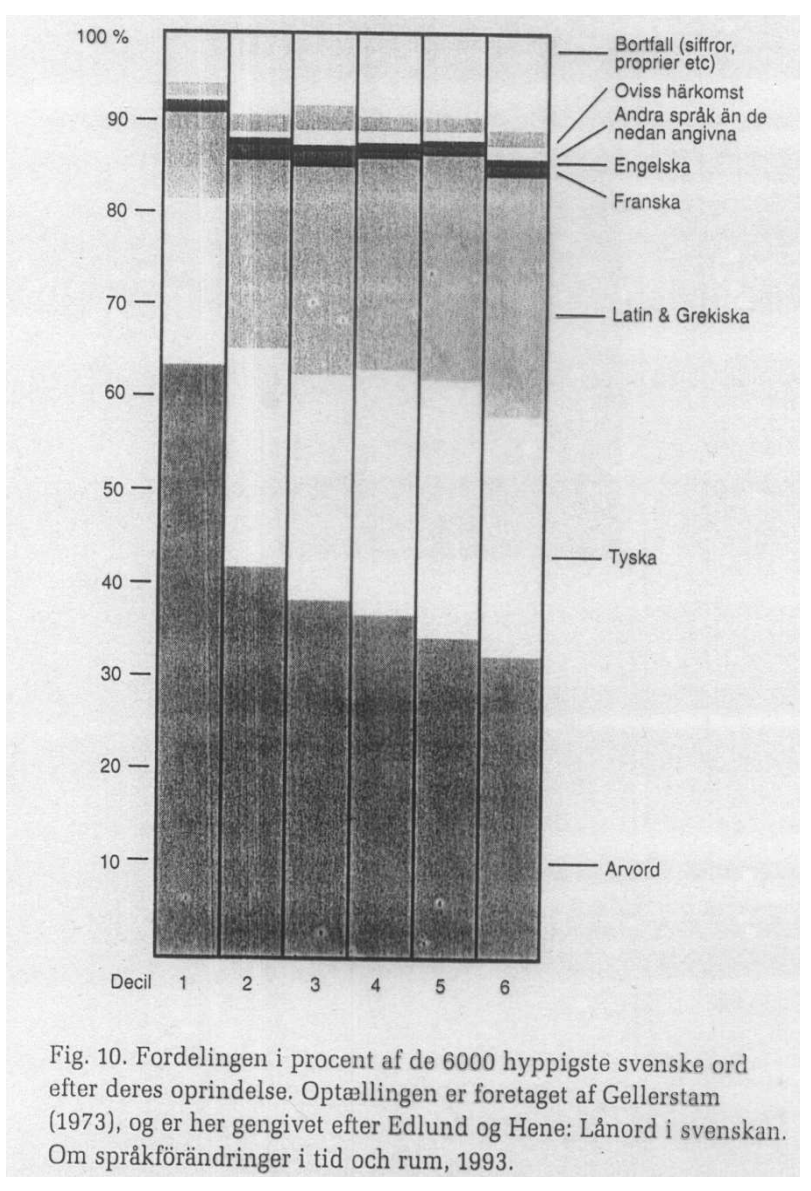


Aby podsumować sytuację języka duńskiego w odniesieniu do wpływów na niego przez język angielski, można przytoczyć wypowiedź Bojsen (1989: 3), która wypowiedziała się w sposób, który obrazuje chyba nie tylko sytuację obecną, ale również odnosi się do historycznego rozwoju języka duńskiego, używając zdaje się przekornie zwrotu pochodzącego z języka angielskiego i moim zdaniem świetnie podsumowującego sytuację:

„Om 500 år vil vi såmænd nok kalde det sprog vi taler til den tid for dansk, om det så også består af plattysk og amerikansk fordelt fifty-fifty."

„Język, którym będziemy się posługiwać za 500 lat, będziemy zapewne nazywać duńskim, bez względu na to, czy będzie się składał po połowie z dolnoniemieckiego i amerykańskiego". (tłum. autora)

\section{Literatura}

Bojsen, E. 1989. „Who's afraid...?”. Nyt fra Sprognavnet 4. 1-3.

Brink, L. 1988. „Nordens folkesprog i fare”. Nyt fra Sprognavnet 4. 4-7.

Davidsen-Nielsen, N. 2010. „Hjælp, engelsk knockouter det danske sprog”. Politiken (18.01. 2010), za http://eplads.norden.org/nordenssprak/kap6/6b.asp?lang=da 31-03-2014.

Davidsen-Nielsen, N. i M. Herslund. 1999. „Dansk han med sin tjener talte”. W: DavidsenNielsen, N., Hansen, E. i P. Jarvad. (red.). Engelsk eller ikke engelsk? That is the question. Engelsk indflydelse på dansk. København: Gyldendal. 11-18.

Edlund, L.-E. i B. Hene. 1992. Lånord i svenskan. Om språkförändringar i tid och rum. Stockholm: Wiken.

Hansen, E. 1985. „Orddannelse på hjemlig grund“. Sprog i Norden. 65-70.

Herslund, M. 1999. „Dansk som >det andet sprog<”. W: Davidsen-Nielsen, N., E. Hansen, E. i P. Jarvad. (red.). Engelsk eller ikke engelsk? That is the question. Engelsk indflydelse på dansk. København: Gyldendal. 19-25.

Jarvad, P. 1995. Nye ord - hvorfor og hvordan? København: Gyldendal.

Jarvad, P. 2001. Det danske sprogs status i 1990'erne med sarligt henblik på domanetab. København: Dansk Sprognævn.

Jarvad, P. 1999a. Nye Ord. Ordbog over nye ord i dansk 1955-1998. København: Gyldendal.

Jarvad, P. 1999b. „Den engelske påvirknings art og mængde”. W: Davidsen-Nielsen, W., Hansen, E. i P. Jarvad. (red.). Engelsk eller ikke engelsk? That is the question. Engelsk indflydelse på dansk. København: Gyldendal. 103-118.

Larsen, F. 1994. „More than loan-words: English influence on Danish”. RASK Internationalt tidsskrift for sprog og kommunikation 1.21-46.

Larsen, F. 1999. „Stands, eller jeg siger bang!”. W: Davidsen-Nielsen, N., Hansen, E. i P. Jarvad. (red.). Engelsk eller ikke engelsk? That is the question. Engelsk indflydelse på dansk. København: Gyldendal. 27-37.

Pedersen, I.L. 2000. „Sprogkontakt, sprogpåvirkning - og sprogpolitik”. Sprog i Norden. 34-44.

Sørensen, K. 1995. Engelsk $i$ dansk. Er det et must? København: Munksgaard. 


\section{Źródła internetowe}

http://eplads.norden.org/nordenssprak/ (31.03.2014)

http://eplads.norden.org/nordenssprak/kap6/6b.asp?lang=da (31-03-2014)

http://www.politiken.dk) (Politiken (19.3.2002)) (21.03.2014)

http://regeringen.se/sb/d/108/a/1443 (21.03.2014)

http://www.kum.dk (21.03.2014)

http://www.norden.org/da/publikationer/publikationer/2004-010 (23.03.2014) 